\title{
Особливості клінічного перебігу пахвинних гриж у хлопчиків залежно від віку та методики операційного втручання
}

\begin{abstract}
Мета роботи: вивчити особливості клінічного перебігу та післяопераційних ускладнень пахвинних гриж у хлопчиків залежно від віку та способу операційного лікування.

Матеріали і методи. Проаналізовано результати доопераційного і післяопераційного перебігу пахвинних гриж у 98 хлопчиків (віком від 1 місяця до 12 років), прооперованих за традиційною або лапароскопічною методиками. Усі хворі розподілені на 2 групи, залежно від методу операційного втручання. Хворим I групи (N=30, середній вік $(1,5 \pm 0,15)$ року) проводили лапароскопічне втручання за методикою PIRS. У II групі ( $\mathrm{N}=68$, середній вік $(4,5 \pm 0,32)$ року) виконували операційне втручання за традиційним методом Duhamel. Критеріями порівняння слугували клінічні прояви до операції та післяопераційні ускладнення на 1,7 доби та через 6 місяців спостереження.

Результати досліджень та їх обговорення. Інтраопераційних ускладнень не виникало ні при лапароскопічних, ні при традиційних методах хірургічного лікування пахвинних гриж у хлопчиків у всіх вікових групах. У I, II та III вікових групах больовий синдром був достовірно більше виражений у підгрупі дітей, оперованих за традиційною методикою, ніж у дітей, оперованих за методикою PIRS, що вимагало додаткового введення ненаркотичних анальгетиків на першу добу післяопераційного спостереження. Рухова активність достовірно швидше наставала (до 6 год) у всіх вікових групах, оперованих за методикою PIRS, ніж за методикою Дюамель. Порівняльний аналіз динаміки змін локального статусу пацієнтів доводить, що лапароскопічна операція PIRS є більш щадною та безпечною щодо елементів сім'яного канатика яєчок. Операційне втручання за методикою PIRS сприяє скороченню термінів локальної та загальної післяопераційної реабілітації у хлопчиків.
\end{abstract}

Ключові слова: пахвинна грижа; лапароскопія (PIRS); традиційна герніотомія.

Постановка проблеми і аналіз останніх досліджень та публікацій. Пахвинна грижа - це найбільш поширена патологія дитячого віку, 3 приводу якої здійснюється основна частка планових операційних втручань. Хлопці страждають від пахвинної грижі у 8-10 разів частіше, ніж дівчата, що пов’язано з порушенням облітерації вагінального відростка очеревини під час процесу опускання яєчка. На сьогодні використовують два методи хірургічного лікування пахвинних гриж: традиційна герніотомія та лапароскопічна герніорафія $[1,2]$. Серед традиційних методик найбільш поширеною є методика Duhamel, a ceред лапароскопічних - PIRS (Percutaneous Internal Ring Suturing). Основним завданням операційного втручання $є$ ліквідація сполучення між черевною порожниною і грижовим мішком. Незважаючи на рутинність виконання методів хірургічного лікування пахвинних гриж, сучасна дитяча хірургія вимагає поліпшення стану оперованих дітей з метою зменшення післяопераційних ускладнень. Після проведених герніотомій часто відмічають нагноєння рани, рецидиви грижі, ішемію та атрофію яєчка [3, 4, 5, 6]. Великий обсяг літератури, яка висвітлює різні аспекти вибору оптимальних технік операційних втручань з метою зменшення виникнення післяопераційних ускладнень, свідчить про важливість проблеми. Разом 3 тим, питання особливостей діагностики та лікування, профілактики ускладнень пахвинної грижі у ран- ньому та пізньому післяопераційному періоді у хлопчиків висвітлено недостатньо. На сьогодні результати хірургічного лікування пахвинних гриж не орієнтовані на подальший прогноз збереження фертильності, відсутні заходи реабілітації таких пацієнтів, недостатньо вивчено вплив операційних втручань на структурно-функціональний стан яєчка у хлопчиків, залишається невідомим факт вибору оптимального методу операційного втручання для збереження фертильності хлопчиків у майбутньому, що й зумовило доцільність нашого обстеження. Тому вивчення питання особливостей клінічного перебігу пахвинної грижі у хлопчиків залежно від віку та проведеного операційного втручання буде сприяти контролю за ефективністю хірургічного лікування з метою зменшення його травматичного впливу на елементи сім'яного канатика, покращення функціональної реабілітації та скорочення термінів одужання.

Мета роботи: вивчити особливості клінічного перебігу та післяопераційних ускладнень пахвинних гриж у хлопчиків залежно від віку та способу операційного лікування.

Матеріали і методи. Проведено вивчення клінічного перебігу та аналіз результатів післяопераційної реабілітації 98 хлопчиків із пахвинними грижами, прооперованих за традиційною або лапароскопічною методиками в II хірургічному відділі Комунальної міської дитячої клінічної лікар- 
ні м. Львова в період 2013-2016 рр. Вік дітей - від 1 місяця до 12 років. Усі хворі розподілені на 2 групи, залежно від методу операційного втручання. Хворим I групи (N=30, середній вік $(1,5 \pm 0,15)$ року) проводили лапароскопічне втручання за методикою PIRS. У II групі ( $\mathrm{N}=68$, середній вік $(4,5 \pm 0,32)$ року) виконували операційне втручання традиційним методом за методикою Дюамеля. Оцінку стану хворих проводили за результатами клінічного обстеження. Порівняльний аналіз обох методик операційного втручання проводили на основі інтраопераційних та післяопераційних показників. Больовий синдром у групах прооперованих дітей оцінювали таким чином: відсутній, помірний, виражений. Появу рухової активності враховували за часом виникнення: до або більше 6 год. Оцінювали косметичний ефект післяопераційної рани як відмінний або добрий.

Результати досліджень та їх обговорення. У новонароджених дітей та дітей раннього віку грижове випинання візуалізувалося у вигляді округлого або овального утвору в пахвинній ділянці. У цій віковій групі збільшення грижового випинання провокували таким чинниками: плач, крик, закреп, кашель, пронос, а в стані спокою воно зни- кало або зменшувалося. Крім того, поява грижового випинання супроводжувалася порушенням загального стану (неспокій, зниження апетиту, блювання), що було більш характерним і вираженим у I віковій групі. У II віковій групі появі і збільшенню грижового випинання сприяли закрепи, надмірний плач, кашель дитини. У старшому віці діти скаржилися на наявність грижового випинання, яке збільшувалося під час ходи і фізичного навантаження та зникало в горизонтальному положенні в стані спокою або під час сну. У дітей старшого віку порушення загального стану не спостерігали.

Інтраопераційних ускладнень не виникало ні при лапароскопічних, ні при традиційних методах хірургічного лікування. При лапароскопічному методі тривалість операційного втручання при однобічній грижі становила $(18,5 \pm 2,5)$ хв, при двобічній - $(27,4 \pm 3,2)$ хв. Операційне втручання за традиційною методикою тривало $(21,3 \pm 2,3)$ при однобічній грижі, а при двобічній - $(28,7 \pm 3,4)$ хв. У ранньому післяопераційному періоді пацієнти практично не скаржилися на біль у місці проведення операційного втручання та ділянці введення троакарів при лапароскопічному операційному втручанні, на відміну від традиційної методики (табл. 1).

Таблиця 1. Динаміка післяопераційного перебігу у хлопчиків залежно від віку та виду операційного втручання

\begin{tabular}{|c|c|c|c|c|c|c|}
\hline \multirow{3}{*}{$\begin{array}{c}\text { Післяопераційний } \\
\text { перебіг та } \\
\text { ускладнення } \\
\text { (загального статусу) }\end{array}$} & \multicolumn{2}{|c|}{ ב1-ша доба } & \multicolumn{2}{|c|}{ При виписуванні (7-ма доба) } & \multicolumn{2}{|c|}{6 міс. } \\
\hline & $A(n=12)$ & $B(n=4)$ & $A(n=12)$ & $B(n=4)$ & $A(n=12)$ & $B(n=4)$ \\
\hline & N (\%) & N (\%) & N (\%) & $\mathrm{N}(\%)$ & N (\%) & N (\%) \\
\hline 1 & 2 & 3 & 4 & 5 & 6 & 7 \\
\hline \multicolumn{7}{|c|}{ I вікова група } \\
\hline $\begin{array}{l}\text { Біль: } \\
\text { відсутній } \\
\text { помірний } \\
\text { виражений } \\
\end{array}$ & $\begin{array}{c}9(75 \%) \\
2(16,7 \%) \\
1(8,3 \%) \\
\end{array}$ & $\begin{array}{l}1(25 \%)^{*} \\
3(75 \%)^{*}\end{array}$ & $\begin{array}{c}12(100 \%) \\
- \\
-\end{array}$ & $\begin{array}{c}3(75 \%) \\
1(25 \%) \\
- \\
\end{array}$ & $\begin{array}{c}12(100 \%) \\
- \\
-\end{array}$ & $\begin{array}{c}4(100 \%) \\
- \\
-\end{array}$ \\
\hline $\begin{array}{l}\text { Початок рухової } \\
\text { активності: } \\
\text { до } 6 \text { год } \\
\text { >6 год }\end{array}$ & $\begin{array}{l}10(83,3 \%) \\
2(16,7 \%)\end{array}$ & $\begin{array}{l}1(25 \%)^{*} \\
3(75 \%)^{*}\end{array}$ & $12(100 \%)$ & $4(100 \%)$ & $12(100 \%)$ & $4(100 \%)$ \\
\hline $\begin{array}{l}\text { Кількість } \\
\text { ліжко-днів }\end{array}$ & $4,17 \pm 0,81$ & $4,50 \pm 0,65$ & $4,17 \pm 0,81$ & $4,50 \pm 0,65$ & $4,17 \pm 0,81$ & $4,50 \pm 0,65$ \\
\hline $\begin{array}{l}\text { Косметичний ефект: } \\
\text { відмінний } \\
\text { добрий }\end{array}$ & $\begin{array}{c}10(83,3 \%) \\
2(16,4 \%)\end{array}$ & $\begin{array}{l}1(25 \%)^{*} \\
3(75 \%)^{*}\end{array}$ & $\begin{array}{c}12(100 \%) \\
-\end{array}$ & $\begin{array}{c}1(25 \%)^{*} \\
3(75 \%)\end{array}$ & $\begin{array}{c}12(100 \%) \\
-\end{array}$ & $\begin{array}{l}1(25 \%)^{*} \\
3(75 \%)\end{array}$ \\
\hline \multicolumn{7}{|c|}{ II вікова група } \\
\hline \multirow{2}{*}{$\begin{array}{l}\text { Післяопераційний } \\
\text { перебіг }\end{array}$} & $A(n=15)$ & $B(n=35)$ & $A(n=15)$ & $B(n=35)$ & $A(n=15)$ & $B(n=35)$ \\
\hline & N (\%) & $\mathrm{N}(\%)$ & $\mathrm{N}(\%)$ & $\mathrm{N}(\%)$ & $\mathrm{N}(\%)$ & $\mathrm{N}(\%)$ \\
\hline $\begin{array}{l}\text { Біль: } \\
\text { відсутній } \\
\text { помірний } \\
\text { виражений }\end{array}$ & $\begin{array}{c}10(66,7 \%) \\
3(20 \%) \\
2(13,3 \%)\end{array}$ & $\begin{array}{c}31(88,5 \%)^{*} \\
4(11,5 \%)\end{array}$ & $15(100 \%)$ & $\begin{array}{l}20(57,1 \%) \\
15(42,9 \%)\end{array}$ & $15(100 \%)$ & $35(100 \%)$ \\
\hline
\end{tabular}


Продовження табл. 1

\begin{tabular}{|c|c|c|c|c|c|c|}
\hline 1 & 2 & 3 & 4 & 5 & 6 & 7 \\
\hline $\begin{array}{l}\text { Початок рухової } \\
\text { активності: } \\
\text { до } 6 \text { год } \\
>6 \text { год }\end{array}$ & $\begin{array}{c}10(66,7 \%) \\
5(33,3 \%)\end{array}$ & $\begin{array}{c}6(17,1 \%)^{*} \\
29(82,9 \%)^{*}\end{array}$ & 15 (100 \%) & 35 (100 \%) & 15 (100 \%) & 35 (100 \%) \\
\hline $\begin{array}{l}\text { Кількість } \\
\text { ліжко-днів }\end{array}$ & $4,73 \pm 0,65$ & $6,57 \pm 0,43 *$ & $4,73 \pm 0,65$ & $6,57 \pm 0,43^{*}$ & $4,73 \pm 0,65$ & $6,57 \pm 0,4^{*}$ \\
\hline $\begin{array}{l}\text { Косметичний ефект: } \\
\text { відмінний } \\
\text { добрий }\end{array}$ & $\begin{array}{c}14(93,3 \%) \\
1(6,7 \%)\end{array}$ & $35(100 \%)$ & $\begin{array}{c}15(100 \%) \\
-\end{array}$ & $\begin{array}{c}3(8,57 \%)^{*} \\
32(91,43 \%)\end{array}$ & $\begin{array}{c}15(100 \%) \\
-\end{array}$ & $\begin{array}{c}5(14,3 \%) \\
30(85,7 \%)\end{array}$ \\
\hline \multicolumn{7}{|c|}{ III вікова група } \\
\hline \multirow{2}{*}{$\begin{array}{c}\text { Післяопераційний } \\
\text { перебіг }\end{array}$} & $A(n=3)$ & $B(n=29)$ & $A(n=3)$ & $B(n=29)$ & $A(n=3)$ & $B(n=29)$ \\
\hline & $\mathrm{N}(\%)$ & $\mathrm{N}(\%)$ & $\mathrm{N}(\%)$ & $\mathrm{N}(\%)$ & N (\%) & $\mathrm{N}(\%)$ \\
\hline $\begin{array}{l}\text { Біль: } \\
\text { відсутній } \\
\text { помірний } \\
\text { виражений } \\
\end{array}$ & $\begin{array}{c}3(100 \%) \\
-\end{array}$ & $\begin{array}{l}9(31 \%)^{*} \\
20(69 \%)\end{array}$ & $3(100 \%)$ & $\begin{array}{c}26(89,7 \%) \\
3(10,3 \%)\end{array}$ & 3 (100 \%) & 29 (100 \%) \\
\hline $\begin{array}{l}\text { Початок рухової } \\
\text { активності: } \\
\text { до } 6 \text { год } \\
>6 \text { год }\end{array}$ & $\begin{array}{c}3(100 \%) \\
-\end{array}$ & $\begin{array}{l}9(31 \%)^{*} \\
20(69 \%)\end{array}$ & $3(100 \%)$ & 29 (100 \%) & 3 (100 \%) & 29 (100 \%) \\
\hline $\begin{array}{l}\text { Кількість } \\
\text { ліжко-днів }\end{array}$ & $5,00 \pm 1,73$ & $6,41 \pm 0,44$ & $5,00 \pm 1,73$ & $6,41 \pm 0,44$ & $5,00 \pm 1,73$ & $6,41 \pm 0,44$ \\
\hline $\begin{array}{l}\text { Косметичний ефект: } \\
\text { відмінний } \\
\text { добрий }\end{array}$ & $\begin{array}{c}3(100 \%) \\
-\end{array}$ & $29(100 \%)$ & $3(100 \%)$ & $\begin{array}{l}10(34,48 \%) \\
19(65,52 \%)\end{array}$ & 3 (100 \%) & $\begin{array}{c}11(38 \%)^{*} \\
18(62 \%)\end{array}$ \\
\hline
\end{tabular}

Примітка. * - достовірна різниця порівняно з А групою $(\mathrm{p}<0,05)$.

У І віковій групі больовий синдром був достовірно більше виражений у підгрупі дітей, оперованих за традиційною методикою, ніж у дітей, оперованих за методикою PIRS, що вимагало додаткового введення ненаркотичних анальгетиків на 1-шу добу післяопераційного спостереження. На 7-му добу в цій підгрупі біль був відсутній або помірного характеру. Рухова активність розпочиналася достовірно швидше у I А групі (до 6 год) 10 (83,3 \%) дітей, ніж у I В групі - 1 (25 \%) дитина, $(\mathrm{p}<0,05)$. Косметичний ефект візуально був достовірно кращий у пацієнтів групи I А, ніж у групі I В, 10 (83,3 \%) і 2 (16,4 \%) відповідно на I-шу добу (p<0,05) та 12 (100 \%) і 1 (25 \%) відповідно через 6 місяців. У ІІ віковій групі А підгрупи больовий синдром достовірно менш виражений (у 10 (66,7 \%) - біль відсутній, у 3 (20\%) - помірний), ніж у II В підгрупі - 31 (88,5 \%) помірний, 4 (11,5 \%) - виражений), $\mathrm{p}<0,05$. Початок рухової активності наставав достовірно швидше у II А групі хлопчиків, ніж у II В групі, а саме 10 (66,7 \%) до 6 (17,1\%), p<0,05. Тривалість перебування на стаціонарному лікуванні була достовірно меншою у групі II A $(4,73 \pm 0,65)$, ніж у групі II B $(6,57 \pm 0,43)$ ліжко-дня. Стан післяоперацій- ної рани та косметичний ефект на першу добу був відмінним у 14 (93,3 \%) пацієнтів II А групи, а в II В групі розцінювався як добрий у 35 (100 \%). На 7-му добу косметичний ефект був також достовірно кращим у II А групі, ніж II В групі пацієнтів: 15 (100 \%) і 3 (8,57 \%) відповідно $(\mathrm{p}<0,05)$. Через 6 місяців спостерігали аналогічну тенденцію. У старшій віковій групі больовий синдром розцінювали як помірний у 3 (100 \%) пацієнтів підгрупи А і 9 пацієнтів (31 \%) підгрупи В та виражений у 20 (69 \%) пацієнтів цієї ж групи, що потребувало додаткового введення ненаркотичних анальгетиків. На 1-шу післяопераційну добу рухова активність достовірно швидше наставала у III А групі - 3 (100 \%), ніж у III В групі - 9 (31 \%), p<0,05. Тривалість перебування пацієнтів III А групи на стаціонарному лікуванні становила $(5,00 \pm 1,73)$ дня, а у III В групі - $(6,41 \pm 0,44)$ ліжко-дня. Візуально косметичний ефект був достовірно кращим у III А групі, ніж у III В групі на 7-му добу та через 6 місяців спостереження: 3 (100 \%) і 10 (34,48 \%) та 3 (100 \%) і 11 (38 \%) відповідно (p<0,05).

У наймолодшій віковій групі хлопчиків на першу добу післяопераційного періоду при локальному огляді пахвинної ділянки та калитки спосте- 
рігали набряк у 2 пацієнтів (16,7 \%) підгрупи А та у 4 (100 \%) підгрупи В $(\mathrm{p}<0,05)$. На 7-му добу спостереження у I А підгрупі набряк був відсутній, а в I В підгрупі набряк утримувався у 3 (75 \%) пацієнтів. Через 6 місяців набряку не було відмічено в обох підгрупах. Зниження кремастерного рефлексу спостерігали на першу добу в 2 (16,7 \%) хлопчиків I А підгрупи і 4 (100 \%) I В підгрупи $(\mathrm{p}<0,05)$. На 7-му добу післяопераційного спостереження кремастерний рефлекс був і надалі зниженим у 3 (75 \%) пацієнтів I В підгрупи. Гематому відмічали на першу та сьому післяопераційні доби тільки у I В підгрупі дітей (табл. 2).

На першу післяопераційну добу набряк калитки був достовірно більш виражений у II В підгрупі 32 (91,4 \%) дітей, ніж у II А підгрупі 3 (20 \%) $(\mathrm{p}<0,05)$. На сьому післяопераційну добу набряк утримувався у 27 (77 \%) хлопчиків II В підгрупи, а у II А підгрупі набряк калитки був відсутній. Гіперемію калитки ми спостерігали тільки в II В підгрупі на першу післяопераційну добу в 12 (34,2 \%) дітей та на 7-му післяопераційну добу в 9 $(25,7$ \%) дітей. Зниження кремастерного рефлексу було більш виражене серед дітей II В підгру- пи 32 (91,4 \%), ніж у пацієнтів II А підгрупи - 3 $(20 \%)(p<0,05)$ на першу післяопераційну добу i в подальшому залишався зниженим тільки у II В підгрупі до 7-ї післяопераційної доби 25 (71,4%). Гематому ми спостерігали тільки у II В підгрупі на першу та сьому доби післяопераційного періоду в $2(5,71 \%)$ та 1 (2,8 \%) хлопчика відповідно (табл. 3).

У III віковій групі хлопців на першу післяопераційну добу ми спостерігали достовірно більш виражений набряк калитки у пацієнтів В підгрупи - 16 (55 \%) і тільки в 1 (33 \%) пацієнта А підгрупи $(\mathrm{p}<0,05)$. На 7-му післяопераційну добу було відмічено набряк калитки у 10 (34,4 \%) пацієнтів В підгрупи. Крім того, на цей період спостереження у 2 (6,9 \%) хлопців даної підгрупи відмічали гіперемію калитки. Достовірне зниження кремастерного рефлексу спостерігали в 1 (33 \%) пацієнта в III А підгрупі і в 16 (55 \%) пацієнтів III В підгрупи на першу добу $(\mathrm{p}<0,05)$. На сьому добу в 10 (34,4 \%) пацієнтів III В підгрупи зниження кремастерного рефлексу було присутне. Гематому відзначали тільки в 2 (6,9 \%) пацієнтів III В підгрупи (табл. 4).

Таблиця 2. Місцеві зміни в післяопераційному періоді I групи (n=16) дітей

\begin{tabular}{|c|c|c|c|c|c|c|}
\hline \multirow{3}{*}{$\begin{array}{c}\text { Післяопераційні } \\
\text { ускладнення } \\
\text { (місцевого характеру) }\end{array}$} & \multicolumn{2}{|c|}{ Сочаток } & \multicolumn{2}{|c|}{ П При виписуванні (7-ма доба) } & \multicolumn{2}{|c|}{6 міс. } \\
\hline & $A(n=12)$ & $B(n=4)$ & $A(n=12)$ & $B(n=4)$ & $A(n=12)$ & $B(n=4)$ \\
\hline & N (\%) & $\mathrm{N}(\%)$ & $\mathrm{N}(\%)$ & $\mathrm{N}(\%)$ & $\mathrm{N}(\%)$ & $\mathrm{N}(\%)$ \\
\hline $\begin{array}{l}\text { Набряк калитки: } \\
\text { наявний } \\
\text { відсутній }\end{array}$ & $\begin{array}{c}2(16,7 \%) \\
10(83,3 \%)\end{array}$ & $\begin{array}{c}4(100 \%)^{*} \\
-\end{array}$ & - & $\begin{array}{c}3(75 \%) \\
-\end{array}$ & - & - \\
\hline Гіперемія калитки & - & $2(50 \%)$ & - & $1(25 \%)$ & - & - \\
\hline $\begin{array}{l}\text { Зниження кремастер- } \\
\text { ного рефлексу: } \\
\text { присутнє } \\
\text { відсутнє }\end{array}$ & $\begin{array}{c}2(16,7 \%) \\
10(83,3 \%)\end{array}$ & $4(100 \%)^{*}$ & - & $3(75 \%)$ & - & - \\
\hline Гематома & - & $2(50 \%)$ & - & $3(75 \%)$ & - & - \\
\hline
\end{tabular}

Примітка. * - достовірна різниця порівняно з А групою (р<0,05).

Таблиця 3. Місцеві зміни в післяопераційному періоді II групи (n=50) дітей

\begin{tabular}{|c|c|c|c|c|c|c|}
\hline \multirow{3}{*}{$\begin{array}{c}\text { Післяопераційні } \\
\text { ускладнення } \\
\text { (місцевого характеру) }\end{array}$} & \multicolumn{2}{|c|}{ Початок } & \multicolumn{2}{|c|}{ При виписуванні (7-ма доба) } & \multicolumn{2}{|c|}{6 мiс. } \\
\hline & $A(n=15)$ & $B(n=35)$ & $A(n=15)$ & $B(n=35)$ & $A(n=15)$ & $B(n=35)$ \\
\hline & $\mathrm{N}(\%)$ & $\mathrm{N}(\%)$ & $\mathrm{N}(\%)$ & N (\%) & $\mathrm{N}(\%)$ & $\mathrm{N}(\%)$ \\
\hline $\begin{array}{l}\text { Набряк калитки: } \\
\text { наявний } \\
\text { відсутній }\end{array}$ & $\begin{array}{c}3(20 \%) \\
12(80 \%)\end{array}$ & $\begin{array}{c}32(91,4 \%)^{*} \\
3(8,6 \%)\end{array}$ & - & $\begin{array}{c}27(77 \%) \\
8(23 \%)\end{array}$ & $15\left(-\frac{-}{100} \%\right)$ & $\begin{array}{c}- \\
35(100 \%)\end{array}$ \\
\hline Гіперемія калитки & - & $12(34,2 \%)$ & - & $9(25,7 \%)$ & - & - \\
\hline $\begin{array}{l}\text { Зниження кремастер- } \\
\text { ного рефлексу: } \\
\text { присутнє } \\
\text { відсутнє }\end{array}$ & $\begin{array}{c}3(20 \%) \\
12(80 \%)\end{array}$ & $\begin{array}{c}32(91,4 \%)^{*} \\
3(8,6 \%)\end{array}$ & - & $\begin{array}{l}25(71,4 \%) \\
10(28,6 \%)\end{array}$ & - & - \\
\hline Гематома & & $2(5,71 \%)$ & - & $1(2,8 \%)$ & - & - \\
\hline
\end{tabular}

Примітка. * - достовірна різниця порівняно з А групою (p<0,05). 
Таблиця 4. Місцеві зміни в післяопераційному періоді III групи (n=32) дітей

\begin{tabular}{|c|c|c|c|c|c|c|}
\hline \multirow{3}{*}{$\begin{array}{c}\text { Післяопераційні } \\
\text { ускладнення } \\
\text { (місцевого характеру) }\end{array}$} & \multicolumn{2}{|c|}{ "Початок } & \multicolumn{2}{|c|}{ П При виписуванні (7-ма доба) } & \multicolumn{2}{|c|}{6 міс. } \\
\hline & $A(n=3)$ & $B(n=29)$ & $A(n=3)$ & $B(n=29)$ & $A(n=3)$ & $B(n=29)$ \\
\hline & $\mathrm{N}(\%)$ & $\mathrm{N}(\%)$ & $\mathrm{N}(\%)$ & $\mathrm{N}(\%)$ & $\mathrm{N}(\%)$ & $\mathrm{N}(\%)$ \\
\hline $\begin{array}{l}\text { Набряк калитки: } \\
\text { наявний } \\
\text { відсутній }\end{array}$ & $\begin{array}{l}1(33 \%) \\
2(67 \%)\end{array}$ & $\begin{array}{c}16(55 \%)^{*} \\
13(45 \%)\end{array}$ & - & $\begin{array}{l}10(34,4 \%) \\
19(65,6 \%)\end{array}$ & - & - \\
\hline Гіперемія калитки & - & $2(6,9 \%)$ & - & - & - & - \\
\hline $\begin{array}{l}\text { Зниження кремастер- } \\
\text { ного рефлексу: } \\
\text { присутнє } \\
\text { відсутнє }\end{array}$ & $\begin{array}{l}1(33 \%) \\
2(67 \%)\end{array}$ & $\begin{array}{c}16(55 \%)^{*} \\
13(45 \%)\end{array}$ & - & $10(34,4$ \%) & - & - \\
\hline Гематома & - & $2(6,9 \%)$ & - & - & - & - \\
\hline
\end{tabular}

Примітка. * - достовірна різниця порівняно з А групою (р<0,05).

Висновки. 1. Інтраопераційних ускладнень не виникало ні при лапароскопічних, ні при традиційних методах хірургічного лікування пахвинних гриж у хлопчиків у всіх вікових групах.

2. У I, II та III вікових групах больовий синдром був достовірно більш виражений у підгрупі дітей, оперованих за традиційною методикою, ніж у дітей, оперованих за методикою PIRS, що вимагало додаткового введення ненаркотичних анальгетиків на першу добу післяопераційного спостереження.

3. Рухова активність достовірно швидше наставала (до 6 год) у всіх вікових групах оперованих за методикою PIRS, ніж за методикою Дюамель.

4. На першу післяопераційну добу набряк калитки був достовірно більш виражений у II В під-

\section{СПИСОК ЛІТЕРАТУРИ}

1. Хірургія дитячого віку / за ред. проф. В. І. Сушка. - К. : Медицина, 2008. - 507 с.

2. Percutaneous internal ring suturing: a simple minimally invasive technique for inguinal hernia repair in children / D. Patkowski, J. Czernik, R. Chrzan [et al.] // J. Laparoendosc. Adv. Surg. Techn. - 2006. - Vol. 16. - P. 513-517.

3. Chang Y. T. Technical refinements in single-port laparoscopic surgery of inguinal hernia in infants and children / Y. T. Chang // Diagnostic and Therapeutic Endoscopy. - 2010. - Vol. 6. - P. 6

4. Minimal access surgery of pediatric inguinal hernias: a review

\section{REFERENCES}

1. Sushko V.I. (2008). (Ed.) Khirurhiia dytiachoho viku [Surgery of childhood]. Kyiv: Medytsyna [in Ukrainian].

2. Patkowski, D., Czernik, J., Chrzan, R., \& Jaworski, W. (2006). Apoznański percutaneous internal ring suturing: a simple minimally invasive technique for inguinal hernia repair in children. $J$. Laparoendosc. Adv. Surg. Techn., 16, 513-517.

3. Chang, Y.T. (2010). Technical refinements in single-port laparoscopic surgery of inguinal hernia in infants and children. Diagnostic and Therapeutic Endoscopy, 6, 6.

4. Saranga, R., Bharathi, R. Arora, M., \& Baskaran, V. (2008). групі дітей, ніж у II А підгрупі. На сьому післяопераційну добу спостереження набряк і надалі утримувався у всіх вікових групах дітей, оперованих за традиційною методикою.

5. Порівняльний аналіз динаміки змін локального статусу пацієнтів доводить, що лапароскопічна операція PIRS є більш щадною та безпечною щодо елементів сім'яного канатика яєчок.

Перспективи подальших досліджень. Подальші дослідження будуть присвячені ефективності фармакологічних методів покращення результатів післяопераційної реабілітації у хлопчиків, прооперованих з приводу пахвинної грижі.

/ R. Saranga, R. Bharathi, M. Arora, V. Baskaran // Surg. Endosc. - 2008. - Vol. 22. - P. 1751-1762.

5. Timberlake M. D. Laparoscopic percutaneous inguinal hernia repair in children: review of technique and comparison with open surgery / M. D. Timberlake, K.W. Herbst, S. Rasmussen // J. Pediatr. Urol. - 2015. -Vol. 11. - P. 1-6.

6 . Feng S. Open versus laparoscopic inguinal herniotomy in children: a systematic review and meta-analysis focusing on postoperative complications / S. Feng, L. Zhao, Z. Liao // Surg. Laparosc. Endosc. Percutan. Tech. - 2015. - Vol. 25. - P. 275-280.

Minimal access surgery of pediatric inguinal hernias: a review. Surg. Endosc. 22, 1751-1762.

5. Timberlake, M.D., Herbst, K.W., \& Rasmussen, S. (2015). Laparoscopic percutaneous inguinal hernia repair in children: Review of technique and comparison with open surgery. J. Pediatr. Urol., 11, 1-6.

6. Feng, S., Zhao, L., \& Liao, Z. (2015). Open versus laparoscopic inguinal herniotomy in children: a systematic review and meta-analysis focusing on postoperative complications. Surg. Laparosc. Endosc. Percutan. Tech., 25, 275-280. 
V.P. ZAHARKO

Danylo Halytskyi Lviv National Medical University

\title{
CLINICAL COURSE OF INGUINAL HERNIA IN BOYS ACCORDING TO AGE AND METHOD OF SURGERY
}

The aim of the work: to study the clinical course and postoperative complications of inguinal hernia in boys according to age and method of surgery.

Materials and Methods. The analysis of the results of postoperative rehabilitation 98 boys with inguinal hernias (in age from 1 month to 12 years) surgically operated on traditional or laparoscopy techniques. All the patients were divided into 2 groups according to operative method. Patients of the group I $(\mathrm{N}=30$, mean age $(1.5 \pm 0.15)$ years) underwent laparoscopic intervention according to the method of PIRS. In group II ( $\mathrm{N}=68$, mean age $(4.5 \pm 0.32)$ we performed surgical intervention according to the Duhamel's traditional method. The criteria for comparison were used as clinical signs prior to surgery and postoperative complications in 1.7 days and 6 months follow-up. Results and Discussion. Intraoperative complications occurred with either laparoscopic or traditional methods during surgical treatment of inguinal hernia in boys in all age groups. In I, II and III age groups, pain was significantly more pronounced in the subgroup of children operated according to traditional methods than children who underwent surgery by the PIRS method, which required the introduction of additional non-narcotic analgesics on the first day postoperative observation. Motor activity significantly advancing faster (up to 6 hours) in all age groups operated by the PIRS method, than by the Duhamel's method. Motor activity significantly advancing faster (up to 6 hours) in all age groups surgically operated by the PIRS method, than by the Duhamel's method. Surgical intervention by the PIRS method helps to reduce terms of local and general postoperative rehabilitation in boys.

Key words: inguinal hernia; testis; laparoscopy (PIRS); traditional herniothomy.

\section{В. П. ЗАХAPKO}

Львовский национальный медицинский университет имени Данила Галицкого

\section{ОСОБЕННОСТИ КЛИНИЧЕСКОГО ТЕЧЕНИЯ ПАХОВЫХ ГРЫЖ У МАЛЬЧИКОВ В ЗАВИСИМОСТИ ОТ ВОЗРАСТА И МЕТОДИКИ ОПЕРАТИВНОГО ВМЕШАТЕЛЬСТВА}

\begin{abstract}
Цель работы: изучить особенности клинического течения и послеоперационных осложнений паховых грыж у мальчиков в зависимости от возраста и способа оперативного лечения.

Материалы и методы. Проанализированы результаты дооперационного и послеоперационного течения паховых грыж у 98 мальчиков (в возрасте от 1 месяца до 12 лет), прооперированных по традиционной или лапароскопической методикам. Все больные разделены на 2 группы в зависимости от метода оперативного вмешательства. Больным I группы (N=30, средний возраст $(1,5 \pm 0,15)$ года) проводили лапароскопическое вмешательство по методике PIRS. Во 2 группе (N=68, средний возраст $(4,5 \pm 0,32)$ года) выполняли оперативное вмешательство по традиционному методу Duhamel. Критериями сравнения служили клинические проявления до операции и послеоперационные осложнения на 1,7 суток и через 6 месяцев наблюдения.

Результаты исследований и их обсуждение. Интраоперационных осложнений не возникало ни при лапароскопических, ни при традиционных методах хирургического лечения паховых грыж у мальчиков во всех возрастных группах. В I, II и III возрастных группах болевой синдром был достоверно более выражен в подгруппе детей, оперированных по традиционной методике, чем у детей, оперированных по методике PIRS, что требовало дополнительного введения ненаркотических анальгетиков в первые сутки послеоперационного наблюдения. Двигательная активность достоверно быстрее наступала (до 6 ч) во всех возрастных группах, оперированных по методике PIRS, чем по методике Дюамель. Сравнительный анализ динамики изменений локального статуса пациентов доказывает, что лапароскопическая операция PIRS более щадящая и безопасная относительно элементов семенного канатика яичек. Оперативное вмешательство по методике PIRS способствует сокращению сроков локальной и общей послеоперационной реабилитации у мальчиков.
\end{abstract}

Ключевые слова: паховая грыжа; лапароскопия (PIRS); традиционная герниотомия.

Отримано 20.01.17 